\title{
Two new species from the mountains of southern Malawi and northern Mozambique
}

\author{
lain Darbyshire ${ }^{1}$,, Roger M. Polhill ${ }^{2}$, Zacharia Magombo ${ }^{3}$ \& Jonathan R. Timberlake ${ }^{4}$
}

Summary. Two new species are described from the proposed Mulanje-Namuli-Ribáuè Centre of Endemism. Isoglossa perdita I.Darbysh. (Acanthaceae) is apparently restricted to the submontane forests of southeastern Mt Mulanje in Malawi, and is assessed as Critically Endangered. Agelanthus patelii Polhill \& Timberlake (Loranthaceae) is recorded from the montane forests of Mt Mulanje and from Mt Namuli in Mozambique, and the earlier assessment of this species as Endangered is confirmed. The habitat preferences and taxonomic affinities of these species are discussed. This work contributes to the ongoing assessment of the biodiversity and endemism of this montane region, and to the identification of Important Plant Areas in Mozambique.

Key Words. Acanthaceae, Centre of Plant Endemism, IUCN Red List assessment, Loranthaceae, montane, new species, taxonomy.

\section{Introduction}

The series of isolated mountains that extends from southern Malawi through Zambézia and Nampula Provinces of northern Mozambique is known to support a rich and varied biodiversity with many unique species (Bayliss et al. 2014). This montane region has been proposed as a (Sub-) Centre of Plant Endemism within the Eastern Afromontane phytogeographical region, provisionally referred to as the Mulanje-Namuli-Ribáuè Centre of Endemism (Darbyshire et al. 2019a).

Mt Mulanje in Malawi, the highest massif in southern tropical Africa, is the best-known of these mountains in botanical terms due to its diverse montane grassland and forest flora, rich in endemic and range-restricted species (Dowsett-Lemaire 1988; White et al. 2001; Strugnell 2002, 2006). Strugnell (2002) recorded 69 species as endemic to this massif and, whilst several of these have since been located on nearby mountains in Mozambique (Harris et al. 2011), it remains a key site for plant endemism with 50 strict endemics documented in an updated assessment (authors' own unpubl. data). The most famous of these is Malawi's national tree, the Mulanje Cedar (Widdringtonia whytei Rendle), a Critically Endangered conifer that is the subject of concerted conservation efforts (Bayliss et al. 2007; Chanyenga et al. 2019).
A recent study of the endemic and near-endemic flora of Mozambique demonstrated that a significant portion (c. 9\%) is restricted to this Centre of Endemism, including 30 Mozambican strict-endemics (Darbyshire et al. 2019a). Many of these species are found on Mt Namuli, a critical site for plant diversity in Mozambique (Timberlake et al. 2009; Harris et al. 2011; Downes \& Darbyshire 2017; Darbyshire et al. 2019b; Timberlake 2021), but other mountains in this centre of endemism are also of high interest for their rare and threatened species and habitats, particularly Mt Mabu and the Ribáuè Mts (Bayliss et al. 2014; Timberlake et al. 2012; Darbyshire et al. 2019a, 2019c). These sites will form an important component of the Important Plant Areas network that is currently being identified and documented in Mozambique as part of the Tropical Important Plant Areas programme (https://www.kew.org/science/our-science/projects/ tropical-important-plant-areas-mozambique; Darbyshire et al. 2019a).

During preparation for the botanical component of a forthcoming biodiversity and endemism assessment of these mountains (J. Bayliss et al., in prep.), two undescribed plant species have been discovered. The first is an Isoglossa Oerst. (Acanthaceae) that is restricted to Mt Mulanje and the second an Agelanthus Tiegh. (Loranthaceae) that is found on both Mulanje

\footnotetext{
Accepted for publication 26 November 2020. Published online 26 March 2021

1 Herbarium, Royal Botanic Gardens Kew, Richmond, Surrey, TW9 3AE, UK. e-mail: i.darbyshire@kew.org

2 The Belt Lodge, Sir Williams Lane, Aylsham, Norwich, NR11 6AN, UK.

3 National Herbarium \& Botanic Gardens of Malawi, P.O. Box 528, Zomba, Malawi.

430 Warren Lane, East Sussex, BN20 OEW, UK.
} 
and Namuli. These species are formally described below and their affinities and conservation status (extinction risk) are discussed.

\section{Materials \& Methods}

Herbarium specimens of the new species were analysed at K and MAL using standard herbarium practices. Prior to dissection, a flower on the $\mathrm{K}$ sheet of the new species of Isoglossa was soaked in Aerosol OT 5\% solution; all other characters were measured on dry material. All duplicates cited have been seen by at least one of the authors, except where indicated ("n.v.").

The species conservation assessments follow the Categories and Criteria of the IUCN Red List (IUCN 2012) and the guidelines for their use (IUCN Standards and Petitions Subcommittee 2019).

\section{Results and Taxonomic Accounts}

\section{A new species of Isoglossa from Mt Mulanje}

The genus Isoglossa (Acanthaceae: Acanthoideae: Justicieae: Isoglossinae; Kiel et al. 2006) is noteworthy for containing a high number of narrowly rangerestricted taxa in tropical and southern Africa (Brummitt 1985; Darbyshire 2009; Darbyshire et al. 2011; Balkwill et al. 2017; Champluvier \& Fischer 2020). When preparing the account of Isoglossa for Flora Zambesiaca (Darbyshire et al. 2015), the first author was surprised by the absence on Mt Mulanje of any species of Isoglossa in the group with an open, paniculate thyrsoid inflorescence and stamens with markedly offset anther thecae - the I. dichotoma (Hassk.) B.Hansen complex sensu Darbyshire (2009). This group is widespread in the montane regions of eastern tropical Africa and several of the larger mountain ranges have one or more endemic taxa in that group (Darbyshire 2009; Darbyshire et al. 2010, 2015). In the Flora Zambesiaca region, this includes I. membranacea C.B.Clarke subsp. membranacea, which is restricted to the Misuku Hills of Malawi, and I. sp. A (= de Koning 7459), known only from an immature flowering specimen from the tea estates of Mt Namuli in Mozambique (Darbyshire et al. 2015). Three species of Isoglossa have been noted previously from $\mathrm{Mt}$ Mulanje: I. grandiflora C.B.Clarke, I. floribunda C.B.Clarke and I. milanjiensis S.Moore. The former two are species of lower elevation, usually riverine woodland and dry forest, and belong to a species group with spiciform inflorescences and anthers with thecae held at an equal height and parallel. Isoglossa milanjiensis, which is also recorded from the Manica Highlands of Mozambique and Zimbabwe, belongs to a group with spiciform inflorescences that are most diverse in South Africa (see Balkwill et al. 2017), and includes the type species of the genus, I. origanoides
(Nees) Lindau (Brummitt 1974). All of these species are quite distinct from the I. dichotoma complex at least in morphological terms; the phylogenetic relationships between and within these groups have not yet been explored.

In processing the accumulated research materials of Dr Richard (Dick) Brummitt at Kew following his sad passing in 2013, several mounted Kew specimens of Isoglossa from Malawi were found that had not been seen at the time of writing the Flora Zambesiaca account. These included a gathering by Francoise Dowsett-Lemaire (her number 949) of an Isoglossa from the I. dichotoma complex, collected from the Chisongeli Forest of Mt Mulanje, which Dr. Brummitt had identified as a possible new species allied to I. membranacea. The Kew specimen is rather scanty, with only incomplete foliage and small inflorescences. However, it has good flowering and fruiting material that allowed it to be compared with the known species in the $I$. dichotoma complex and confirmed as a distinctive new species. A duplicate of this specimen was subsequently discovered at the MAL herbarium. It is described below as I. perdita.

Isoglossa perdita is the fourth taxon of Isoglossa that is endemic to Malawi, the others being I. eliasbandae Brummitt from the Zomba Plateau, I. membranacea subsp. membranacea (see above) and I. pawekiae Brummitt \& Feika from riverine thickets and woodland in the Misuku area (Darbyshire et al. 2015). In Mozambique, Mt Namuli also supports an endemic species in the I. origanoides group, namely I. namuliensis I.Darbysh. (Harris et al. 2011).

Isoglossa perdita I.Darbysh. sp. nov. Type: Malawi, Southern Region, Chisongeli, south-east slopes of $\mathrm{Mt}$ Mulanje, 29 Aug. 1983, F. Dowsett-Lemaire 949 (holotype $\mathrm{K}$; isotype MAL).

http://www.ipni.org/urn:lsid:ipni.org:names:77214825-1

Isoglossa sp. (nº 949) sensu Dowsett-Lemaire (1988: 97).

Shrub 1-2 m tall; young branches quadrangular, with inconspicuous short pale retrorse hairs mainly in two opposite grooves and around the nodes. Cauline leaves only seen in incomplete state, \pm elliptic, base attenuate, margin entire, apex acuminate; leaves subtending inflorescences with blade ovate to ovate-elliptic, 25 $78 \times 14-35 \mathrm{~mm}$, base shallowly cordate, apex attenuate, adaxial surface with scattered conspicuous multicellular hairs appearing deflated in dry state, most numerous along margin, abaxial surface with somewhat shorter hairs along main veins, cystoliths linear, conspicuous in dry state; petiole to $32 \mathrm{~mm}$ long, pilose along adaxial groove, these hairs continuing along the blade midrib adaxially, leaves 
subtending the inflorescence sessile. Inflorescence (perhaps not fully developed) a slender paniculate thyrse to $41 \mathrm{~mm}$ long including primary peduncle 11 $22 \mathrm{~mm}$ long, few-branched, the branches monochasial or partially dichasial, with flowers clustering towards branch apices; inflorescence axes eglandularpuberulous and with numerous long crisped glandular hairs up to $2 \mathrm{~mm}$ long, these multicellular, appearing deflated in dry state and with a small gland-tip; bracts and bracteoles minute, lanceolate or triangular, 0.7 $1.2 \mathrm{~mm}$ long; pedicels absent or less than $1 \mathrm{~mm}$ long. Calyx lobes linear-lanceolate, $3-3.6 \mathrm{~mm}$ long, barely lengthening in fruit, apices slightly recurved, indumentum as that of inflorescence axes externally, shortly appressed-pubescent internally. Corolla pinkishwhite, 12.3 - $14 \mathrm{~mm}$ long, pubescent externally, hairs longest ventrally; tube $7.5-8.2 \mathrm{~mm}$ long, with basal cylindrical portion $\pm 5.5 \times 1.6 \mathrm{~mm}$ and short abruptly ventrally-deepened throat; upper lip broadly triangular and hooded, $4-5 \mathrm{~mm}$ long, apex 2-lobed for \pm 1.5 $\mathrm{mm}$, somewhat reflexed; lower lip $5-5.8 \mathrm{~mm}$ long, with 3 lobes $1.5-1.9 \mathrm{~mm}$ long, palate somewhat raised with "herring-bone" patterning and central furrow, glabrous. Stamens inserted at apex of cylindrical portion of tube; filaments free for $4-4.5 \mathrm{~mm}$, glabrous; anthers exserted, with thecae superposed and oblique, narrow, each $1.1-1.2 \mathrm{~mm}$ long, muticous. Pistil glabrous; style $7.5-8.3 \mathrm{~mm}$ long; stigma shortly bilobed. Capsule 18 - $19 \mathrm{~mm}$ long, stipitate, glabrous; seeds not seen. Fig. 1 .

RECOGNITION. Resembling Isoglossa membranacea but differing in the corolla tube being longer, 7.5 $8.2 \mathrm{~mm}$ long, and clearly divided into a basal cylindrical portion and a short deepened throat (vs $4.5-7 \mathrm{~mm}$ long and subcampanulate, without a conspicuous basal cylindrical portion); having a larger capsule $18-19 \mathrm{~mm}$ long and glabrous (vs capsule 8.5 - $11.5 \mathrm{~mm}$ long and puberulous and/or pilose); the inflorescences having long crisped glandular hairs to $2 \mathrm{~mm}$ long with an inconspicuous gland-tip (vs glandular hairs not crisped, up to $1 \mathrm{~mm}$ long, with a more conspicuous gland-tip); and stamens with filaments free for $4-4.5 \mathrm{~mm}$ (vs $2-2.5 \mathrm{~mm}$ ).

DISTRIBUTION. This species is known only from the type specimen from Mt Mulanje in the Southern Region of Malawi.

SPECIMEN EXAMINED. MALAWI. Southern Region, Mulanje Distr., Mt Mulanje, Chisongeli, south-east slopes of Mt Mulanje, fl. \& fr., 29 Aug. 1983, F. Dowsett-Lemaire 949 (K holotype, MAL isotype).

HABITAT \& ECOLOGY. The single known specimen was recorded from shade near a stream in moist submontane rainforest at $1300 \mathrm{~m}$ elevation, on the rain-facing southeastern slopes of Mulanje. The forest at Chisongeli was dominated by Newtonia buchananii (Baker f.) G.C.C.Gilbert \& Boutique, with Gambeya gorungosana (Engl.) Liben and Trilepisium madagascariense DC. also common. The understorey contained abundant Vepris nobilis (Delile) Mziray, with Myrianthus holstii Engl. and Tabernaemontana stapfiana Britten, and with Acanthaceae taxa frequent in the ground layer including this Isoglossa species (DowsettLemaire 1988 \& pers. comm.).

CONSERVATION STATUS. To date, this species is only known from the type locality in the Chisongeli Forest in southeast Mt Mulanje. This is despite the fact that Mt Mulanje has been the focus of considerable botanical study, and suggests that this species is naturally rare. On the other hand, it is quite possible that this is a plietesial species in line with other species of Isoglossa (Thomas 1996; Darbyshire 2009; Darbyshire et al. 2011; Champluvier \& Fischer 2020) with periodic massflowering on a cycle spanning several years. If this is the case, this species may have been overlooked during nonflowering years. Chisongeli was previously the largest single block of forest in Malawi, extending from $900-$ $1800 \mathrm{~m}$ elevation. Between the early 1970s and 1984, it is estimated that the Chisongeli Forest shrank by $34 \%$ from $38 \mathrm{~km}^{2}$ to $25 \mathrm{~km}^{2}$ (Dowsett-Lemaire 1988). The forest below $1650 \mathrm{~m}$, including the Newtonia-dominated forest in which this species occurred, was extensively destroyed in the 1980s due to expansion of subsistence agriculture (BirdLife International 2020; F. Dowsett-Lemaire, pers. comm.), hence the population at the type locality may no longer be extant. Many other areas of low or midelevation forest on the southern slopes of Mt Mulanje have been cleared or degraded (BirdLife International 2020). Some good quality Newtonia-dominated forest remains in the Ruo Gorge area but this site has also suffered from severe encroachment at lower elevations (Dowsett-Lemaire 1988). There is some hope that this species may be rediscovered in these remaining midelevation forest patches on the mountain. Based on current evidence, with one location known, a maximum area of occupancy (AOO) of less than $10 \mathrm{~km}^{2}$ and with a continuing decline in extent and quality of habitat, this species must be considered Critically Endangered - CR (PE) B2ab(iii). The Possibly Extinct ("PE") tag is included in view of the fact that this species has not been recorded in 37 years and suitable habitat at its only confirmed location has been largely destroyed.

ETYMOLOGY. The species epithet "perdita" means "lost" and refers both to the fact that the holotype collection was "lost" for many years, and to the fact that this species may now be lost due to destruction of its forest habitat.

\section{A new species of Agelanthus from Mts Mulanje and Namuli}

The genus Agelanthus (Loranthaceae) currently comprises 60 accepted species in tropical and southern Africa, and hence is the largest genus of African Loranthaceae (Polhill \& Wiens 1998; POWO 2020). In 


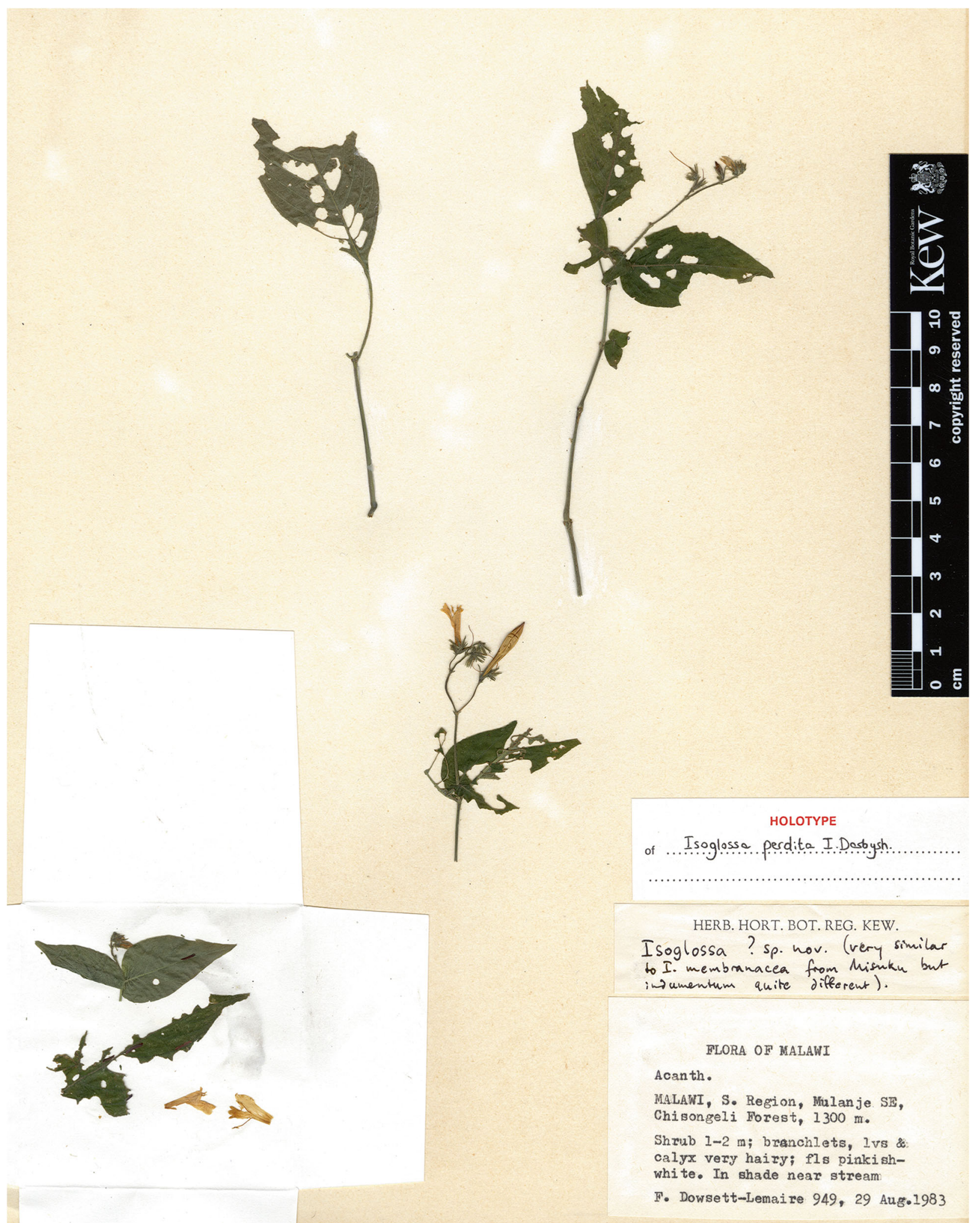

Fig. 1. Photograph of holotype of Isoglossa perdita (F. Dowsett-Lemaire 949, K) from Mt Mulanje, Malawi. 
the account of Loranthaceae for Flora Zambesiaca (Polhill \& Wiens 2006), the second author of the current work included an incompletely known species, Agelanthus sp. near A. brunneus (Engl.) Balle \& N. Hallé, based on a specimen collected by Jim and Betty Chapman in 1986 from the northern slopes of $\mathrm{Mt}$ Mulanje. At that time there was insufficient material to fully describe it; in particular the flowers were immature and it was not certain what colour they were. In 2008, a flowering specimen of mistletoe was collected from the forest/grassland plateau on $\mathrm{Mt}$ Namuli, which, on subsequent identification at Kew, was seen to be very similar to the Mulanje specimen. These specimens are here described as a new species of Agelanthus section Agelanthus (Polhill \& Wiens 1998), named as A. patelii Polhill \& Timberlake.

Agelanthus patelii Polhill E Timberlake sp. nov. Type: Mozambique, Mt Namuli, 23 Nov. 2008, I. H. Patel 2 (holotype K; isotype LMA [n.v.]).

http://www.ipni.org/urn:lsid:ipni.org:names:77214826-1

Agelanthus sp. 1 sensu Polhill in White et al. (2001: 349).

Agelanthus sp. aff. A. brunneus (Engl.) Balle \& N. Hallé sensu Polhill \& Wiens (2006: 162).

Small shrub, glabrous except for some small brown hairs at the base of inflorescences and on bracts; branchlets angular, soon terete. Leaves alternate; petiole $1-2 \mathrm{~mm}$ long; lamina $3.5-9 \times 1-1.8 \mathrm{~cm}$ (no doubt considerably larger when mature), narrowly elliptic-lanceolate, tapered or slightly acuminate to an acute apex, long-cuneate and somewhat decurrent at base, with few lateral nerves, the lowest strongly ascending. Flowers clustered in the axils; pedicels $1-2 \mathrm{~mm}$ long; bract 2-3 mm long, cupular with a small triangular limb, ciliolate and with some scattered hairs. Receptacle c. 2 mm long; calyx 1.2 - 2 mm long, tubular, ciliolate. Corolla yellowish, c. $5 \mathrm{~cm}$ long; apical swelling slight, fusiform; basal swelling not evident in bud, but c. $5 \mathrm{~mm}$ long and ellipsoid as flower matures; lobes 20 - $25 \mathrm{~mm}$ long; upper expanded part 8 - $10 \mathrm{~mm}$ long, linear-elliptic. Stamen filaments with distal several $\mathrm{mm}$ broader, tightly coiled and corrugated without a tooth; anthers c. $4 \mathrm{~mm}$ long. Style slender, isodiametric; stigma c. $1.2 \mathrm{~mm}$ across, ovoid. Mature fruit not seen, but said to be pink (H. Patel, pers. comm.). Fig. 2.

RECOGNITION. Differing from other species in Agelanthus sect. Agelanthus with a basal swelling on the mature corolla by the corolla lobes being about half as long as the tube (vs a quarter to a third as long).

DISTRIBUTION. This species is known only from Mt Mulanje in Southern Region of Malawi and Mt Namuli from Zambézia Province in northern Mozambique. However, although not collected during recent studies, it is possible this species may also be found in similar nearby montane forests on Mts Chiperone and Mabu in Mozambique.

SPECIMENS EXAMINED. MALAWI. Southern Region, Mulanje Distr., Mt Mulanje, Chipalombe (Thuchila R.), $\pm 15^{\circ} 51^{\prime} 30^{\prime \prime S}, 35^{\circ} 39^{\prime} 13^{\prime \prime E}, 1480 \mathrm{~m}$, fl. bud, 20 Aug. 1986, J. D. Eं E. G. Chapman 7985 (FHO, K, MAL). MOZAMBIQUE. Zambézia Province, Gurué Distr., Mt Namuli, Mukotcha (Manho) Forest, 15²3'57.4"S, 3702'33.7"E, 1712 m, fl., 23 Dec. 2008, I. H. Patel 2 (K holotype, LMA isotype n.v.).

HABITAT \& ECOLOGY. This species has been collected on Englerophytum magalismontanum (Sond.) T.D.Penn. in montane forest on dry rocky slopes (Chapman 7985) and on Maesa lanceolata Forssk. on a montane forest margin (Patel 2), between 1480 and 1712 m elevation.

CONSERVATION STATUS. This species is listed as Endangered - EN B1ab(iii)+2ab(iii) on the IUCN Red List (Timberlake et al. 2018). It is particularly threatened on Mt Namuli, where there is ongoing destruction of montane forest (Timberlake et al. 2009; Timberlake 2017), with an estimated loss of over $20 \%$ of forest cover in the decade 2008 - 2018. The remaining extent of montane forest (mostly over $1400 \mathrm{~m}$ elevation) on these two massifs is now estimated at 1900 ha $\left(19 \mathrm{~km}^{2}\right)$ on Mt Mulanje and 700 ha $\left(7 \mathrm{~km}^{2}\right)$ on Mt Namuli.

ETYMOLOGY. The species is named after the Malawian botanist Hassam Patel, who has collected on most of the Malawi and Mozambican mountains in the region, and who collected the first fully flowering specimen.

NOTES. This is an interesting species belonging to the complex around Agelanthus brunneus, widespread in Guineo-Congolian forests from Senegal to Uganda and western Kenya, with several satellite species in the highlands of eastern Africa. It differs from all these species by its relatively long corolla lobes. The basal swelling of the corolla, characteristic of most of this group, only becomes marked as the corolla matures in A. patelii, rather similarly to what can occur in the polymorphic A. brunneus. The shape of the swollen part of the corolla lobes, widest near the middle, rather than towards the apex, is also like A. brunneus. Patel mentions the flowers were yellowish, without more detail, but other satellite species of A. brunneus in the mountains further north have yellow corollas with a band of white and subsidiary red/orange and/ or green bands around the vents: A. krausei (Engl.) Polhill \& Wiens from Rwanda and Western Uganda, and A. pennatulus (Sprague) Polhill \& Wiens from the highlands of Kenya and Tanzania. The flowers of A. brunneus are variable in colour with the tube variously white to pink, or green to yellow or orange, 


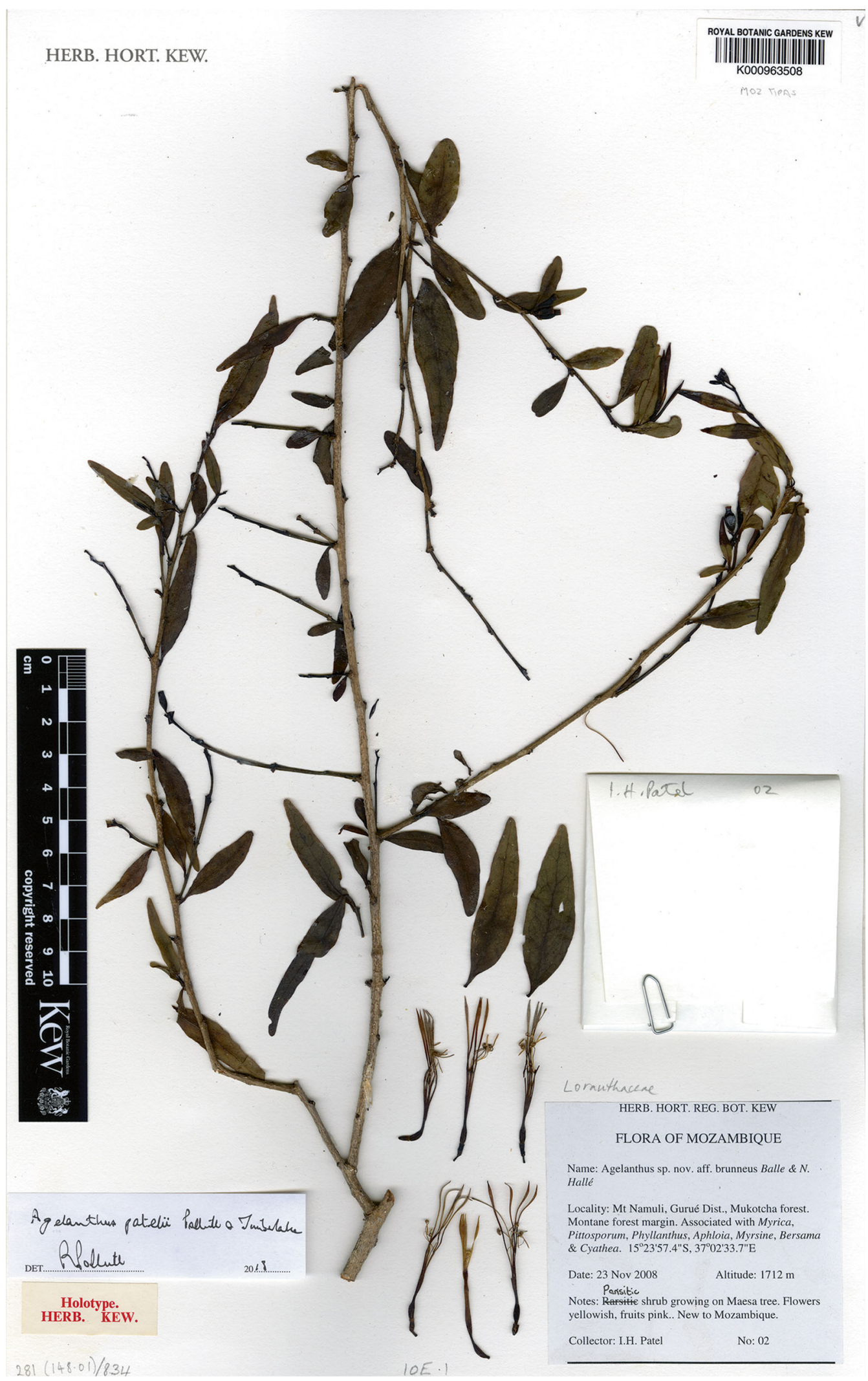

Fig. 2. Photograph of holotype of Agelanthus patelii (I. H. Patel 2, K) from Mt Namuli, Mozambique. 
with contrasting bands of colour at the base of the lobes and generally white over the vents, but descriptions on field labels are often imprecise.

The description could be amplified by additional flowering material, the Chapman specimens being only in bud and the Patel specimen at Kew with the flowers in a packet being seemingly fallen dead ones collected from the ground, with only a young fruit still on the plant. It is hoped that this initial description will draw attention to the plant so that it can be rediscovered and suitably illustrated in the future.

\section{Acknowledgments}

We thank Francoise Dowsett-Lemaire for providing useful information on the forests of Mt Mulanje and on the history of her plant collections from her surveys of the Mulanje forests. The Instituto de Investigação Agrária de Moçambique (IIAM), and in particular Camila de Sousa and Tereza Alves, are thanked for organising the plant collecting permits associated with the 2008 expedition to Mt Namuli in Mozambique which was conducted under the Darwin Initiative Award 15/ 036: Monitoring and Managing Biodiversity Loss in SouthEast Africa's Montane Ecosystems. I.D. wishes to thank Oppenheimer Philanthropies and Stephen and Margaret Lansdown for their generous support of the Tropical Important Plant Areas: Mozambique project. Finally, we thank Roy Gereau of Missouri Botanical Garden for his helpful comments on a draft of this manuscript.

Open Access This article is licensed under a Creative Commons Attribution 4.0 International License, which permits use, sharing, adaptation, distribution and reproduction in any medium or format, as long as you give appropriate credit to the original author(s) and the source, provide a link to the Creative Commons licence, and indicate if changes were made. The images or other third party material in this article are included in the article's Creative Commons licence, unless indicated otherwise in a credit line to the material. If material is not included in the article's Creative Commons licence and your intended use is not permitted by statutory regulation or exceeds the permitted use, you will need to obtain permission directly from the copyright holder. To view a copy of this licence, visit http://creativecommons.org/ licenses/by/4.0/.

\section{References}

Balkwill, K., Sebola, R. J. \& Poriazis, D. L. (2017). Taxonomic revision of white-flowered Isoglossa Oerst. (Acanthaceae) in southern Africa. S. African J. Bot. 108: 48-80.

Bayliss, J., Makungwa, S., Hecht, J. \& Nangoma, D. (2007). Saving the Island in the Sky: the plight of the Mount Mulanje cedar Widdringtonia whytei in Malawi. Oryx 41: $64-69$.

, Timberlake, J., Branch, W., Bruessow, C., Collins, S., Congdon, C., Curran, M., de Sousa, C., Dowsett, R., Dowsett-Lemaire, F., Fishpool, L., Harris, T., Herrmann, E., Georgiadis, S., Kopp, M., Liggitt, B., Monadjem, A., Patel, H., Ribeiro, D., Spottiswoode, C., Taylor, P., Willcock, S. \& Smith, P. (2014). The discovery, biodiversity and conservation of Mabu forest - The largest medium-altitude rainforest in southern Africa. Oryx 48: 177 - 185.

BirdLife International (2020). Important Bird Areas factsheet: Mount Mulanje Forest Reserve. Available at: http://datazone.birdlife.org/site/factsheet/ mount-mulanje-forest-reserve-iba-malawi [accessed 17 June 2020].

Brummitt, R. K. (1974). Proposal to conserve 8079 Isoglossa Örsted. over Rhytiglossa Nees ex Lindley (Acanthaceae). Taxon 23: 440 - 441.

(1985). Additions to the tropical African species of Isoglossa (Acanthaceae). Kew Bull. 40: 785 - 791.

Champluvier, D. \& Fischer, E. (2020). Isoglossa darbyshirei (Acanthaceae), a new plietesial species from the Albertine Rift (Rwanda, Burundi). Phytotaxa 438: 276 - 288.

Chanyenga, T., Shaw, K. \& Mitole, I. (2019). Widdringtonia whytei. The IUCN Red List of Threatened Species 2019: e.T33216A126090798. Available at: https://doi.org/10.2305/IUCN.UK.20193.RLTS.T33216A126090798.en. [accessed June 2020].

Darbyshire, I. (2009). Taxonomic notes and novelties in the genus Isoglossa (Acanthaceae) from East Africa. Kew Bull. 64: 401 - 427.

Langa, C. \& Romeiras, M. M. (2019c). A synopsis of Polysphaeria (Rubiaceae) in Mozambique, including two new species. Phytotaxa 414: 1 - 18.

, Pearce, L. \& Banks, H. (2011). The genus Isoglossa (Acanthaceae) in west Africa. Kew Bull. 66: $425-439$.

Timberlake, J., Osborne, J., Rokni, S., Matimele, H., Langa, C., Datizua, C., de Sousa, C., Alves, T., Massingue, A., Hadj-Hammou, J., Dhanda, S., Shah, T. \& Wursten, B. (2019a). The endemic plants of Mozambique: diversity and conservation status. PhytoKeys 136: 45 - 96.

Vollesen, K. \& Ensermu Kelbessa (2010). Acanthaceae (Part 2). In: H. J. Beentje (ed.), Flora of Tropical East Africa. Acanthaceae (Part 2). Royal Botanic Gardens, Kew.

\& _ (2015). Acanthaceae (Part 2). In: J.

R. Timberlake \& E. S. Martins (eds), Flora Zambesiaca Vol. 8 (6). Royal Botanic Gardens, Kew. Wursten, B., Luke, Q. \& Fischer, E. (2019b). A revision of the Crepidorhopalon whytei complex (Linderniaceae) in eastern Africa. Blumea 64: 165 -176 . 
Downes, E. \& Darbyshire, I. (2017). Coleus namuliensis and Coleus caudatus (Lamiaceae): a new species and a new combination in the Afromontane flora of Mozambique and Zimbabwe. Blumea 62: 168 - 173.

Dowsett-Lemaire, F. (1988). The forest vegetation of Mt Mulanje (Malawi): a floristic and chorological study along an altitudinal gradient $(650-1950 \mathrm{~m})$. Bull. Jard. Bot. Natl. Belg. 59: 77 - 107.

Harris, T., Darbyshire, I. \& Polhill, R. (2011). New species and range extensions from Mt Namuli, Mt Mabu and Mt Chiperone in northern Mozambique. Kew Bull. 66: 241 - 251.

IUCN (2012). IUCN Red List Categories and Criteria. Version 3.1. Second Edition. IUCN Species Survival Commission, Gland \& Cambridge.

IUCN Standards and Petitions Committee (2019). Guidelines for Using the IUCN Red List Categories and Criteria. Version 14. Prepared by the Standards and Petitions Committee. Available at: http:// ww w . i u c n r ed lis t . org/d oc u m e n t s / RedListGuidelines.pdf [accessed 20 April 2020]

Kiel, C. A., McDade, L. A., Daniel, T. F. \& Champluvier, D. (2006). Phylogenetic delimitation of Isoglossinae (Acanthaceae: Justicieae) and relationships among constituent genera. Taxon 55: 683 -694 .

Polhill, R. \& Wiens, D. (1998). Mistletoes of Africa. Royal Botanic Gardens, Kew.

\& _ (2006). Loranthaceae. In: G. V. Pope, R. M. Polhill \& E. S. Martins (eds), Flora Zambesiaca, Vol. 9 (3): 117 - 195. Royal Botanic Gardens, Kew.

POWO (2020). Plants of the World Online. Facilitated by the Royal Botanic Gardens, Kew. Available at: http://www.plantsoftheworldonline.org/ [accessed 17 June 2020].

Strugnell, A. M. (2002). Endemics of Mt. Mulanje. The endemic spermatophytes of Mt. Mulanje, Malawi. Syst. Geogr. Pl. 72: $11-26$.

(2006). A checklist of the Spermatophytes of Mount Mulanje, Malawi. Scripta Bot. Belg. 34. National Botanic Garden of Belgium, Meise.
Thomas, D. (1996). Synchronously flowering monocarpic Acanthaceae in the montane forests of Cameroon. Acanthus 6: 2.

Timberlake, J. (2017). Mt Namuli - a conservation update. Unpublished report to Legado, Mozambique, March 2017.

(2021). A first plant checklist for Mt. Namuli, northern Mozambique. Kirkia 19: 191 - 225.

Bayliss, J., Dowsett-Lemaire, F., Congdon, C., Branch, B., Collins, S., Curran, M., Dowsett, R. J., Fishpool, L., Francisco, J., Harris, T., Kopp, M. \& de Sousa, C. (2012). Mt Mabu, Mozambique: biodiversity and conservation. Report for Darwin Initiative Award 15/036: Monitoring and Managing Biodiversity Loss in South-East Africa's Montane Ecosystems. Royal Botanic Gardens, Kew.

, Dowsett-Lemaire, F., Bayliss, J., Alves, T., Baena, S., Bento, C., Cook, K., Francisco, J., Harris, T., Smith, P. \& de Sousa, C. (2009). Mt Namuli, Mozambique: Biodiversity and Conservation. Report produced under Darwin Initiative Award 15/036. Royal Botanic Gardens, Kew.

, Matimele, H. A., Darbyshire, I., Alves, M. T., Chelene, I., Cumbula, S., Datizua, C., de Sousa, C., Langa, C., Massingue, A. O., Mucaleque, P. A., Odorico, D., Osborne, J., Rokni, S., Viegas, A. \& Vilanculos, A. (2018). Agelanthus patelii. The IUCN Red List of Threatened Species 2018: e.T120960913A120980328. Available at: https:// d o i . org / 10.2305 / I U C N . U K. 2018 2.RLTS.T120960913A120980328.en. [accessed 17 June 2020].

White, F., Dowsett-Lemaire, F. \& Chapman, J. D. (2001). Evergreen Forest Flora of Malawi. Royal Botanic Gardens, Kew.

\section{Publisher's Note}

Springer Nature remains neutral with regard to jurisdictional claims in published maps and institutional affiliations. 